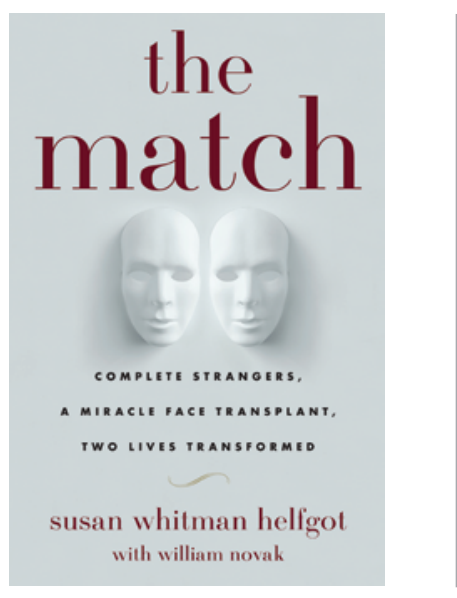

\section{The match}

\author{
Complete strangers, a miracle face transplant, \\ two lives transformed
}

Susan Whitman Helfgot with William Novak

Simon and Schuster. New York, New York, USA. 2010.

272 pp. \$26.00. ISBN: 978-1-439-19548-2 (hardcover).

Reviewed by Carson Strong

University of Tennessee Health Science Center, Memphis, Tennessee, USA

E-mail: cstrong@uthsc.edu
$T_{b}$ be Match gives an inside story of the second face transplant operation in the United States, performed in 2009 at the Brigham and Women's Hospital in Boston. The author is Susan Whitman Helfgot, wife of heart patient Joseph Helfgot, who suffered a stroke in the operating room while receiving a heart transplant. Susan Helfgot recounts a story centered around her agreeing to donate her husband's face for transplantation. Helfgot collaborated with William Novak, the accomplished biographer of Magic Johnson, Lee Iacocca, Tip O'Neil, and Nancy Reagan, among others. Aimed at a general audience, The Match has an easy-to-read style and its apparent purpose is to provide a first-hand account of a story of considerable interest to the public and media.

The book reveals many facets of the events surrounding this partial face transplantation. Susan Helfgot describes her thoughts and feelings day by day, sometimes hour by hour, as she made her way through an extraordinary series of events. These included her interactions with the organ procurement organization, the support of her family and friends during and after making the decision to donate, and the immediate turn from the donation decision to the funeral of her husband. They also included a loss of the usual anonymity surrounding organ donation, which resulted from media probing, as well as the donor family and recipient learning - without agreeing to do so - each other's identities. Helfgot and Novak do a nice job of describing these experiences, particularly the demands and stresses of being the ongoing subject of media attention.
The book is written in a novelistic style, jumping back and forth from the present to the past, from one location to another. This method recommends itself because several stories are being told, interwoven with each other. One is the story of who Joseph Helfgot was: the child of Auschwitz survivors who settled in the Lower East Side of New York City. Outgoing and energetic, Joseph Helfgot rose from poverty to become a sociology professor and later a successful entrepreneur in market research for the entertainment industry. Another story recounts the background and experiences of James Maki, the face transplant recipient. Maki is a mixed Blackfoot Indian and Japanese orphan who was adopted by a Japanese couple living in Seattle. As a young man, Maki served in Vietnam, where he witnessed unspeakable tragedy and fell into heroin addiction. After the war, his life was taken over by drug abuse. One evening when he was high, he fell off a subway platform and landed face first on the third rail. This accident left him horribly disfigured, with the middle of his face missing - no nose or upper mouth and one eye stitched shut. Eating, swallowing, speaking, and even breathing became difficult.

Also woven through the book is a medical story. It describes the role of the organ procurement agency in bringing together donor and recipient, seeking consent for donation, and coordinating the various activities that are part of any transplantation. It also portrays the study and preparation of the surgeons and the complexities of having a large team of health professionals involved in the removal and transplant of potentially multiple organs.
The authors present the transplant operation in a favorable light. This is understandable because there are a number of positive things about it; Susan Helfgot's decision to donate her husband's face to help a man in great need demonstrated generosity worthy of commendation. But the book lacks an even-handed approach when the authors discuss whether human facial transplants should be carried out at present - a matter concerning which there is considerable disagreement. There are good arguments, based on both scientific and ethical concerns, that our knowledge about immunosuppression is not advanced enough to justify clinical facial transplantation at this time (1-3). However, the authors do not mention these serious objections and instead characterize the opposition as a group who claim that facial transplantation is "nothing more than a stunt" and that the transplant surgeons are "a bunch of fools." Thus, the authors' description of the debate is a caricature in which the substance of the objections is presented as little more than name calling. They state, decisively, "the naysayers were wrong. This was the right thing to do."

Putting aside the fact that this controversy is misrepresented, the book will be of interest to many readers. Written in a clear and engaging style, it does indeed give a rare glimpse into a remarkable series of events.

1. Maschke KJ, Trump E. Facial transplantation research: A need for additional deliberation. $A m J$ Bioethics. 2004;4(3):33-35.

2. Rohrich RJ, Longaker MT, Cunningham B. On the ethics of composite tissue allotransplantation (facial transplantation). Plast Reconstr Surg. 2006;117(6):2071-2073.

3. Strong C. An ongoing issue concerning facial transplantation. Am J Transplant. 2010;10(5):1115-1116. 